\title{
Foreword
}

\section{David Marsden}

It is 20 years since the publication of the Supiot Report, Au delà de l'emploi, and the call by a distinguished group of European legal and employment scholars to re-think employment law. How should employment rights adapt to emerging organizational practices of businesses and changing patterns of households. 'Fordist' employment practices of large firms were giving way to more flexible patterns among smaller firms, often working in networks and on a project basis, and driven by changes in technology and product market competition. On the household side, employment and social protection law, modelled on the 'male breadwinner model', was leaving increasing numbers of workers with inappropriate protection. Twenty years on, the rise in the numbers of self-employed, particularly among the highly qualified, and the increased variety and complexity of the tasks they undertake, accentuate the need to adapt the modes of employment and social protection, and the style of representation.

This multi-country study traces out the new opportunities for selfemployed professionals. These relate mainly to greater opportunities for autonomous work, being one's own boss, and how global platforms have expanded the market for their services. This has also brought greater flexibility regarding the time and location of their work, and potentially improved work-life balance. Nevertheless, the study also shows how these advantages have come with the risk of greater job insecurity, gaps between projects, lower incomes, and lesser social protection. While the long-established Fordist model of employment, with relatively stable long-term jobs, had a clear demarcation between 'insiders' and 'outsiders', in the sectors of independent professionals, these lines are being redrawn. Although these 'i-Pros' often cluster into communities of practice, which provide a source of job information and reputational control, to become a recognized member may require a long period low paid and insecure work as extended entry tournaments have come to replace established entry paths into employment.

When considering new forms of legislation to improve the employment rights and social protection of workers in self-employment and in the large 
grey area between that and employee status, one needs a good map of current practice. Above all one needs to know more about the individual and collective strategies that these workers develop in order to ensure a fair bargain. Employment law was long dominated by the 'gold standard' of full-time, long-term, employment as this had emerged from the demands of large-scale capitalist employers and the aspirations of workers and their unions. Although they had conflicting demands over distribution, they frequently shared a common interest in productivity and real wage growth. As Sumner Slichter showed in his classic studies of the rise of collective bargaining in the US economy, large-scale employers shared an interest in stabilizing employment and developing skills, and the norm of full-time long-term jobs provided a contractual framework that suited the interests of both parties.

The chapters in this study illustrate how much the systems of production and service provision have changed over recent decades. The employment law reforms of the mid-twentieth century did not invent what has become known as 'the standard employment contract'. Rather, they sought to build on the employment norms that had evolved out of the interests of labour and employers of their day. Their aim was to consolidate these, and limit abuses. The challenge in the new environment is to identify the emerging patterns and norms of the penumbra that has grown around this contractual form. Then we can begin to consider what practices facilitate new modes of exchange, and what are the abuses that need to be controlled. As Fritz Scharpf observed in the Games real actors play, employment rules need not be a source of rigidity. Very often they facilitate cooperation by reassuring the parties concerned that what he calls 'worst case scenarios' have been ruled out, or at least made less likely. In real life prisoners' dilemmas, cooperation is difficult to achieve because the other party has a stronger incentive to defect than to cooperate. But well-designed institutions can make this less likely, so the fruits of cooperation can be enjoyed.

It is hard to conceive such practices in the abstract. One of the values of this study, is that it complements information on the 'top-down' initiatives by established representative institutions, with an account of the 'bottomup' self-organizing activities. Both are important. The top-down approach can help resolve collective action problems. In contrast, the bottom-up approach is often closer to the immediate dilemmas faced by these workers to balance the flexibility needed to expand their activities with the need for protection from the risks of disloyal behaviour by their contracting partners. By studying these, one can form a picture of the forms of disloyal behaviour to which freelancers and the self-employed themselves know they are exposed, as well as the solutions they have sought to develop. For many self-employed professionals, the cost of production of their service is 
great, whereas its reproduction is relatively cheap, so that intellectual and artistic property are major concerns. Thus, the British Musicians Union has adapted special norms to regulate recordings in order to protect their members from theft. Likewise, the Writers' Union provides a service to lodge manuscripts in case of disputes over originality. Lacking the workplace as a location of organization, some of these workers have developed new forms of connectivity, exploiting the same platform technologies that have displaced the firm as an employing organization. Exploring these devices provides clues to the development of functional equivalents to the protections that characterize the standard employment relationship. With such protections, these independent professionals can more confidently expand their services, and society benefits. They also provide valuable clues as to the paths for collective action and new forms of employment legislation.

More generally, the findings of this study call for a rethink of the theory of the firm as an employing organisation. The classic works on the modern firm, of Chester Barnard, Ronald Coase and Herbert Simon, derive from the period when 'managerial capitalism' was consolidating its hold. They contrasted the exchange of labour services governed by an open market 'sales contract' with the employment contract governed by an authority relationship. Historically, this made sense as the old contract system was being displaced by the spread of the employment relationship. The growing importance today of hybrid forms of employment and their diversity, as documented in this study, highlight the need to re-think not just employment, but also the nature of employing organisations.

David Marsden Professor of Industrial Relations London School of Economics 
David Marsden - 9781788118453 Downloaded from PubFactory at 04/26/2023 02:51:18PM via free access 